\title{
Efficacy of botanicals in managing pod borers in pigeonpea [Cajanus cajan (L.) Millsp.]
}

\author{
C.S. Jagadeesh Babu' ${ }^{1 *}$, B.S. Rajendra Prasad ${ }^{2}$ and M. Byregowda ${ }^{1}$
}

\begin{abstract}
An experiment was conducted to evaluate different botanicals for the management of pod borers in pigeonpea [Cajanus cajan (L.) Millsp.] for two years (20122014) at the Zonal Research Station of the University of Agricultural Sciences, Bangalore, India. Pod damage by Helicoverpa armigera (Hubner) in the experimental area ranged from $10.64 \%$ to $23.07 \%$. The first spray of neem soap followed by $(f b)$ two sprays of the insecticide indoxacarb, and indoxacarb alone sprayed thrice were effective in reducing pod damage caused by $\mathrm{H}$. armigera. Incidence of Maruca vitrata (Geyer), Melanagromzya obtusa (Malloch) and Callosobruchus spp. was comparatively low during the two-year study period. Botanicals alone did not perform well in controlling the pod borers. However, one spray of these botanicals $f b$ spraying indoxacarb twice resulted in effective control of the pests. The higher yields were recorded in indoxacarb-treated plots $(1,290 \mathrm{~kg} / \mathrm{ha})$, neem seed kernel extract (NSKE) sprayed thrice $(1,258 \mathrm{~kg} / \mathrm{ha})$ and one spray of NSKE $f b$ with two sprays of indoxacarb $(1,257 \mathrm{~kg} / \mathrm{ha})$.
\end{abstract}

Keywords: Botanicals, pod borers, Helicoverpa armigera, pigeonpea

\section{Introduction}

Pigeonpea [Cajanus cajan (L.) Millsp.] is a major leguminous crop in the tropics and subtropics and accounts for $5 \%$ of the world's legume production (Hillocks et al., 2000). About 2.8 million ha are under pigeonpea cultivation in the world where India alone accounts for 2.5 million ha. Pigeonpea yields have remained stagnant for the past three to four decades. Among many biotic and abiotic factors responsible for low yields of pigeonpea, insect pests are the major causal factor. Though the pest spectrum of pigeonpea crop includes more than 200 species of insects and mites, the major insects causing heavy crop losses are the pod borers such as Helicoverpa armigera (Hubner), pod fly (Melanagromyza obtusa Malloch), webworm (Maruca vitrata Geyer) and Bruchids (Callosobruchus spp.). Management of different pod borers in pigeonpea relies heavily on insecticides where the farmers spend a considerable portion of the cost of cultivation in pigeonpea cultivation. However, due to lack of adequate technical knowledge at the grass root level, farmers resort to excessive use of pesticides.

\footnotetext{
1 AICRP (Pigeonpea), University of Agricultural Sciences, GKVK, Bangalore, Karnataka, India

2 Department of Entomology, University of Agricultural Sciences, GKVK, Bangalore-, Karnataka, India

* jagadeesh5k@rediffmail.com
} 
Crop surveys have indicated that before 1975 , only $20 \%$ of the pigeonpea farmers have used insecticides, however, by 1993 100\% of the farmers have adopted chemicals to control pod borers in India. Estimates show that more than US\$ 1 billion has been spent on insecticides to control the pod borers affecting this crop. Application of three to six sprays of chemicals is a common practice in pigeonpea cultivation to protect the crop from pod borers. Due to the continuous and excessive use of insecticides, the insect pests have developed a considerable level of resistance to most of the conventional insecticides, including the synthetic pyrethroids (Kranthi et al., 2002). Natural enemy activity on pod borers in pigeonpea is relatively low as compared to that on other crops such as sorghum (Bhatnagar et al., 1983). The enhanced use of pesticides has posed a serious health hazard and has led to the development of more serious pest problems, which have become a threat to the environment.

The rapid increase in pesticide use on pigeonpea is alarming and emphasizes raising farmers' concern on damages caused by insect pests. The recent trends also highlight the need for safe and effective alternate management strategies to reduce the reliance on insecticides alone. Botanicals have become a devise that suite the holistic approach to control these insect pests in pigeonpea. Hence, an experiment was conducted to evaluate the efficacy of new formulations of botanicals, namely neem soap and pongamia soap (the oil-based formulation from the Indian Institute of Horticultural Research, Bangalore) for the management of pod borers in pigeonpea cultivation.

\section{Materials and Methods}

The field trial was conducted to evaluate different formulations of botanicals for the management of pod borers of pigeonpea [Cajanus cajan (L.) Millsp.] for two consecutive years during kharif season in 2012-2013 and 2013-2014 at the Zonal Research Station, University of Agricultural Sciences, Bangalore, India. The pigeonpea cultivar BRG-2 was used for the experiment in a randomized complete block design with three replicates. Eight treatments (Table 1) were imposed with an untreated control. The plot size was $4 \mathrm{~m} \times 4.5 \mathrm{~m}$ and spacing between rows and plants was $90 \mathrm{~cm}$ and $20 \mathrm{~cm}$, respectively. Three sprays were given with an interval of ten days starting from $50 \%$ flowering. Totally $700 \mathrm{~L}$ of spray solution was used per ha. Observations on pod damage were recorded in 50 randomly selected plants. The \% damage was estimated by counting both damaged and total number of pods (Equation 1), while assessment was also made on the damage due to individual species of pod borer complex by considering the damaged pods based on feeding and hole-emergence pattern i.e. large round and regular holes referred to $\mathrm{H}$. armigera, the irregular scrapping and holes on the pods refer to $M$. vitrata, the pinhead size holes at the peripheral end refer to $M$. obtusa and the small round hole at the centre of the 
pod refer to Callosobruchus sp. (Figure 1). The plot yields were also recorded. The percentage data was subjected to arc sine transformation and statistical interpretation of data was done by following the Fischer's analysis of variance (Panse and Sukhatme, 1967).

Per cent pod damage $=\frac{\text { Number of pods damaged }}{- \text { Total number of pods in the sample }^{\text {En }}} \quad$ Equation 1

\section{Results and Discussion}

The results revealed that the pod damage by $\mathrm{H}$. armigera was the lowest in indoxacarb-treated plots (12.52\%) followed by NSKE (16.23\%). Use of botanicals as the first spray followed by $(\mathrm{fb})$ the insecticide indoxacarb during the year 2012-2013 also showed promising results (Table 1). The control of pod fly and bruchids also followed a similar trend. The highest yield was obtained in indoxacarb-treated plots and those that received neem soap as the first spray $f b$ two sprays of indoxacarb recording a yield of 1,631 and 1,607 kg/ha, respectively, and were significantly superior $(p<0.05)$ to most of the other treatments.

During the year 2013-14, the pod damage by $H$. armigera was low compared to the previous year (Table 2). Plots treated with neem soap $f b$ indoxacarb and NSKE $f b$ indoxacarb recorded the lowest pest infestation (4.07 and 4.84, respectively). The incidence of all other insect pest was also low during the second year of the experiment. However, the highest yield was obtained from plots treated with neem soap $f b$ indoxacarb application and indoxacarb alone with 954 and $949 \mathrm{~kg}$ per ha, respectively, and the yields were significantly higher $(p<0.05)$ compared to most of the other treatments.

Pooled data for the years 2012-2014 showed that the pod damage by $\mathrm{H}$. armigera ranged from $10.64 \%$ to $23.07 \%$ in different treatment combinations (Table 3). The plots that received the first spray of neem soap fb two sprays of indoxacarb, and those that received three sprays of indoxacarb alone fared better in reducing pod damage by $\mathrm{H}$. armigera (10.64\%), which is the main pest. The plots treated with neem soap $f b$ two sprays of the insecticide indoxacarb (11.47\%) also significantly reduced $(p<0.05)$ the pest incidence. Incidence of $M$. vitrata, M. obtusa and Callosobruchus spp was comparatively low during the twoyear study period. Botanicals alone did not perform well in controlling pod borers. However, one spray of the botanicals $f b$ application of indoxacarb twice resulted in better control of the pests. The highest crop yield was recorded in the indoxacarb-treated plots with $1,290 \mathrm{~kg} / \mathrm{ha}$ followed by plots that sprayed thrice with NSKE $(1,258 \mathrm{~kg} / \mathrm{ha})$ and first spray with NSKE fb two sprays of indoxacarb $(1,257 \mathrm{~kg} / \mathrm{ha})$. The results confirm the findings Sunil et al. (2004) who reported that Dipe ${ }^{\oplus} 8 \mathrm{~L}$ (Bacillus thuringiensis Kurstaki) used in combination with fresh neem leaf extract was effective in controlling $H$. armigera on pigeonpea. 
Table 1. Efficacy of botanicals for the management of pod borers in pigeonpea during 2012-2013

\begin{tabular}{|c|c|c|c|c|c|c|}
\hline Treatments & Dose & Helicoverpa & Maruca & Podfly & Bruchids & Yield (kg/ha) \\
\hline Neem soap (three times) & $10 \mathrm{~g} / \mathrm{L}$ & $20.44(22.31)^{c}$ & $3.32(10.18)^{a}$ & $14.05(21.72)^{\mathrm{bc}}$ & $12.15(20.22)^{\mathrm{ab}}$ & $1000^{c}$ \\
\hline $\begin{array}{l}\text { Pongamia soap (three } \\
\text { times) }\end{array}$ & $10 \mathrm{~g} / \mathrm{L}$ & $24.48(31.78)^{b}$ & $3.76(10.93)^{a}$ & $15.27(22.98)^{b c}$ & $10.65(19.02)^{\mathrm{abc}}$ & $760^{c d}$ \\
\hline NSKE* (three times) & $50 \mathrm{~g} / \mathrm{L}$ & $16.23(19.64)^{c}$ & $3.63(10.66)^{a}$ & $12.98(20.94)^{c}$ & $10.29(18.52)^{\mathrm{abc}}$ & $1588^{\mathrm{ab}}$ \\
\hline Indoxacarb (three times) & $0.5 \mathrm{ml} / \mathrm{L}$ & $12.52(14.01)^{d}$ & $2.89(9.46)^{a}$ & $11.94(20.00)^{c}$ & $8.38(16.74)^{c}$ & $1631^{\mathrm{a}}$ \\
\hline $\begin{array}{l}\text { Neem soap } f b \text { indoxacarb } \\
\quad f b \text { indoxacarb }\end{array}$ & $\begin{array}{c}10 \mathrm{~g} / \mathrm{L} ; 0.5 \mathrm{ml} / \mathrm{L} ; \\
0.5 \mathrm{ml} / \mathrm{L}\end{array}$ & $17.20(21.33)^{c}$ & $3.27(10.42)^{a}$ & $15.60(22.99)^{b c}$ & $8.16(16.41)^{c}$ & $1274^{\mathrm{b}}$ \\
\hline $\begin{array}{l}\text { Pongamia soap } f b \\
\text { indoxacarb } f b\end{array}$ & $\begin{array}{l}10 \mathrm{~g} / \mathrm{L} ; 0.5 \mathrm{ml} / \mathrm{L} ; \\
\quad 0.5 \mathrm{ml} / \mathrm{L}\end{array}$ & $20.65(22.60)^{c}$ & $3.58(10.67)^{a}$ & $15.92(23.37)^{b c}$ & $9.07(17.45)^{b c}$ & $1201^{\mathrm{bc}}$ \\
\hline $\begin{array}{l}\text { NSKE } f b \text { indoxacarb } f b \\
\text { indoxacarb }\end{array}$ & $\begin{array}{c}50 \mathrm{~g} / \mathrm{L} ; 0.5 \mathrm{ml} / \mathrm{L} ; \\
0.5 \mathrm{ml} / \mathrm{L}\end{array}$ & $18.10(41.55)^{a}$ & $3.33(10.42)^{a}$ & $17.66(24.74)^{b}$ & $11.60(19.70)^{\mathrm{abc}}$ & $1607^{\mathrm{a}}$ \\
\hline Untreated & & $49.79(44.85)^{\mathrm{a}}$ & $4.91(11.91)^{\mathrm{a}}$ & $22.60(28.36)^{\mathrm{a}}$ & $13.41(21.40)^{\mathrm{a}}$ & $538^{d}$ \\
\hline SEM \pm & & 4.25 & NS & 2.93 & NS & 128.20 \\
\hline$C D(p=0.05)$ & & 12.02 & - & 8.94 & - & $367 \cdot 34$ \\
\hline $\mathrm{CV}(\%)$ & & 16.66 & 19.16 & 14.80 & 16.20 & 13.08 \\
\hline
\end{tabular}

* NSKE = neem seed kernel extract; SEM = Standard error of the mean; CD = critical difference; CV = co-efficient of variability; $f b=$ followed by.

Within a column, means followed by the same letter are not significantly different at $p=0.05$. 
Table 2. Efficacy of botanicals for the management of pod borers in pigeonpea during 2013-2014

\begin{tabular}{|c|c|c|c|c|c|c|}
\hline Treatments & Dose & Helicoverpa & Maruca & Podfly & Bruchids & Yield (kg/ha) \\
\hline Neem soap (three times) & $10 \mathrm{~g} / \mathrm{L}$ & $19.93(26.46)^{a}$ & $2.53(8.78)^{a}$ & $5.05(12.38)^{a}$ & $5.35(13.05)^{a}$ & $774^{\mathrm{a}}$ \\
\hline $\begin{array}{l}\text { Pongamia soap (three } \\
\text { times) }\end{array}$ & $10 \mathrm{~g} / \mathrm{L}$ & $21.66(27.58)^{a}$ & $1.72(7.49)^{\mathrm{a}}$ & $7.49(15.52)^{a}$ & $4.00(11.31)^{\mathrm{ab}}$ & $659^{\mathrm{ab}}$ \\
\hline NSKE* (three times) & $50 \mathrm{~g} / \mathrm{L}$ & $9.63(17.64)^{b}$ & $1.62(7.16)^{a b}$ & $5.95(14.07)^{a}$ & $5.34(13.09)^{a}$ & $927^{a}$ \\
\hline Indoxacarb (three times) & $0.5 \mathrm{ml} / \mathrm{L}$ & $8.76(16.98)^{b}$ & $1.33(6.41)^{\mathrm{ab}}$ & $4.19(11.76)^{a}$ & $4.31(11.81)^{a b}$ & $949^{a}$ \\
\hline $\begin{array}{l}\text { Neem soap fb indoxacarb } f b \\
\text { indoxacarb }\end{array}$ & $\begin{array}{c}10 \mathrm{~g} / \mathrm{L} ; 0.5 \mathrm{ml} / \mathrm{L} ; \\
0.5 \mathrm{ml} / \mathrm{L}\end{array}$ & $4.07(11.39)^{b}$ & $1.53(7.07)^{a b}$ & $3.13(10.10)^{a}$ & $4.55(12.07)^{a b}$ & $954^{a}$ \\
\hline $\begin{array}{l}\text { Pongamia soap } \mathrm{fb} \\
\text { indoxacarb fb } \\
\text { indoxacarb }\end{array}$ & $\begin{array}{c}10 \mathrm{~g} / \mathrm{L} ; 0.5 \mathrm{ml} / \mathrm{L} ; \\
0.5 \mathrm{ml} / \mathrm{L}\end{array}$ & $19.24(25.89)^{a}$ & $0.49(4.01)^{b}$ & $7.66(15.52)^{a}$ & $1.99(7.87)^{\mathrm{ab}}$ & $844^{a}$ \\
\hline $\begin{array}{l}\text { NSKE fb indoxacarb fb } \\
\text { indoxacarb }\end{array}$ & $\begin{array}{c}50 \mathrm{~g} / \mathrm{L} ; 0.5 \mathrm{ml} / \mathrm{L} ; \\
0.5 \mathrm{ml} / \mathrm{L}\end{array}$ & $4.84(12.59)^{b}$ & $0.48(3.96)^{b}$ & $5.50(13.02)^{a}$ & $1.65(7.23)^{b}$ & $907^{a}$ \\
\hline Untreated & & $23.28(28.60)^{a}$ & $2.63(9.22)^{a}$ & $7.71(15.96)^{a}$ & $4.11(11.67)^{a b}$ & $370^{b}$ \\
\hline SEM \pm & & 2.37 & 1.01 & 2.09 & 1.68 & 123.83 \\
\hline$C D(p=0.05)$ & & 7.18 & 3.07 & 6.33 & 5.08 & 375.53 \\
\hline $\mathrm{CV}(\%)$ & & 19.63 & 25.95 & 26.70 & 26.37 & 26.88 \\
\hline
\end{tabular}

* NSKE = neem seed kernel extract; SEM = Standard error of the mean; CD = critical difference; CV = co-efficient of variability; $\mathrm{fb}=$ followed by

Within a column, means followed by the same letter are not significantly different at $p=0.05$. 
Table 3. Efficacy of botanicals for the management of pod borers in pigeonpea during 2012-2014

\begin{tabular}{|c|c|c|c|c|c|c|}
\hline Treatments & Dose & Helicoverpa & Maruca & Podfly & Bruchids & Yield (kg/ha) \\
\hline Neem soap (three times) & $10 \mathrm{~g} / \mathrm{L}$ & $20.18(26.68)^{b}$ & $2.92(9.80)^{\mathrm{ab}}$ & $9.55(17.94)^{b c}$ & $8.75(17.19)^{\mathrm{a}}$ & $887^{\mathrm{cd}}$ \\
\hline $\begin{array}{l}\text { Pongamia soap (three } \\
\text { times) }\end{array}$ & $10 \mathrm{~g} / \mathrm{L}$ & $21.86(27.84)^{b}$ & $2.74(9.51)^{b c}$ & $11.38(19.67)^{b}$ & $7.33(15.68)^{\mathrm{abc}}$ & $710^{d}$ \\
\hline NSKE* (three times) & $50 \mathrm{~g} / \mathrm{L}$ & $18.95(25.77)^{b}$ & $2.62(9.26)^{b c}$ & $9.47(17.90)^{b c}$ & $7.82(16.16)^{a b}$ & $1258^{a}$ \\
\hline Indoxacarb (three times) & $0.5 \mathrm{ml} / \mathrm{L}$ & $10.64(18.97)^{c}$ & $2.11(8.33)^{b c}$ & $8.72(17.11)^{c}$ & $6.35(14.52)^{b c}$ & $1290^{a}$ \\
\hline $\begin{array}{l}\text { Neem soap fb indoxacarb } \\
f b \text { indoxacarb }\end{array}$ & $\begin{array}{c}10 \mathrm{~g} / \mathrm{L} ; 0.5 \mathrm{ml} / \mathrm{L} ; \\
0.5 \mathrm{ml} / \mathrm{L}\end{array}$ & $13.42(21.37)^{c}$ & $2.40(8.88)^{b c}$ & $11.66(19.91)^{b}$ & $6.35(14.48)^{b c}$ & $1114^{\mathrm{ab}}$ \\
\hline $\begin{array}{l}\text { Pongamia soap } f b \\
\text { indoxacarb } f b \\
\text { indoxacarb }\end{array}$ & $\begin{array}{c}10 \mathrm{~g} / \mathrm{L} ; 0.5 \mathrm{ml} / \mathrm{L} ; \\
0.5 \mathrm{ml} / \mathrm{L}\end{array}$ & $12.36(20.57)^{c}$ & $2.04(8.19)^{c}$ & $9.53(17.97)^{b c}$ & $5.53(13.56)^{c}$ & $1022^{\mathrm{bc}}$ \\
\hline $\begin{array}{l}\text { NSKE } f b \text { indoxacarb } f b \\
\text { indoxacarb }\end{array}$ & $\begin{array}{c}50 \mathrm{~g} / \mathrm{L} ; 0.5 \mathrm{ml} / \mathrm{L} ; \\
0.5 \mathrm{ml} / \mathrm{L}\end{array}$ & $11.47(19.77)^{c}$ & $1.91(7.92)^{c}$ & $10.92(19.29)^{b c}$ & $6.63(14.83)^{b c}$ & $1257^{\mathrm{a}}$ \\
\hline Untreated & & $36.54(37.17)^{a}$ & $3.77(11.18)^{a}$ & $15.13(22.83)^{\mathrm{a}}$ & $8.76(17.16)^{a}$ & $454^{e}$ \\
\hline SEM \pm & & 0.58 & 0.28 & 0.42 & 0.64 & 35.75 \\
\hline$C D(p=0.05)$ & & 1.76 & 0.84 & 1.27 & 1.94 & 108.41 \\
\hline CV (\%) & & 7.03 & 9.06 & 6.59 & 7.16 & 10.74 \\
\hline
\end{tabular}

* NSKE = neem seed kernel extract; SEM = Standard error of the mean; CD = critical difference; CV = co-efficient of variability; $\mathrm{fb}=$ followed by

Within a column, means followed by the same letter are not significantly different at $p=0.05$. 


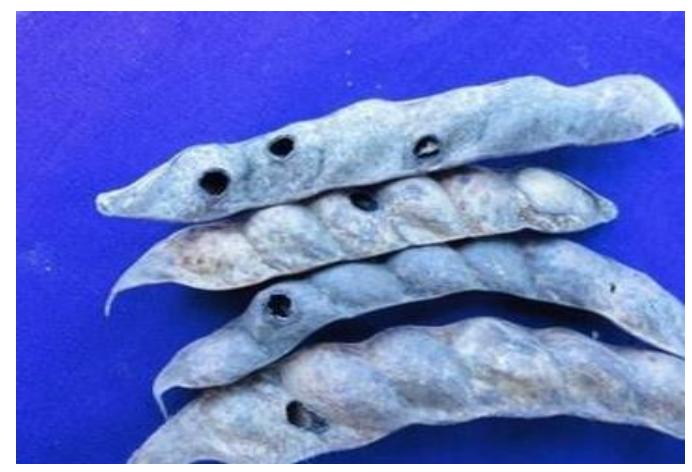

Helicoverpa armigera

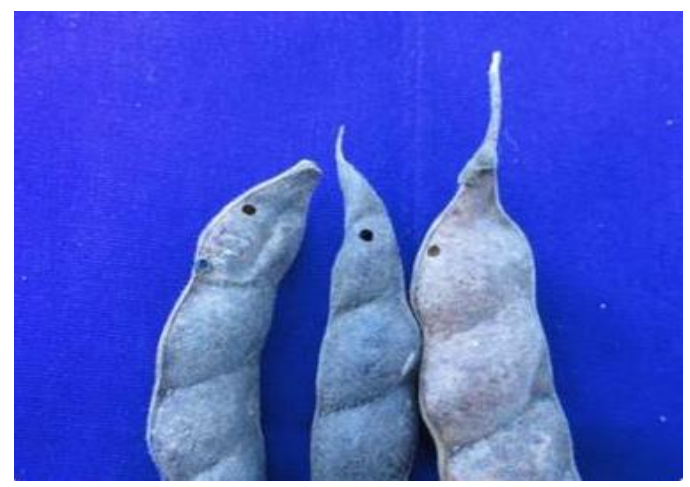

Melanagromyza obtusa

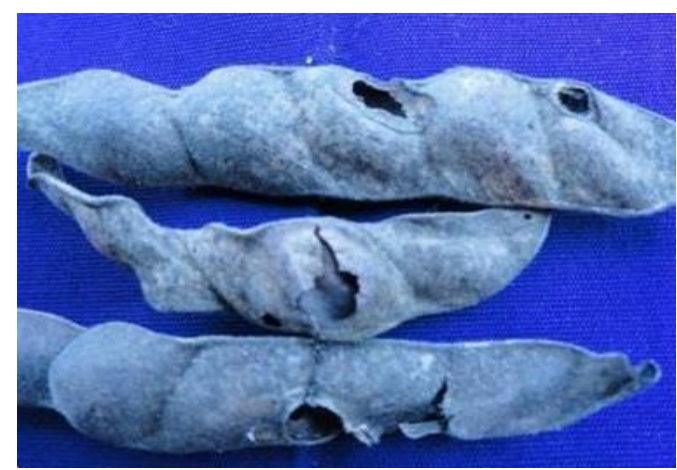

Maurca vitrata

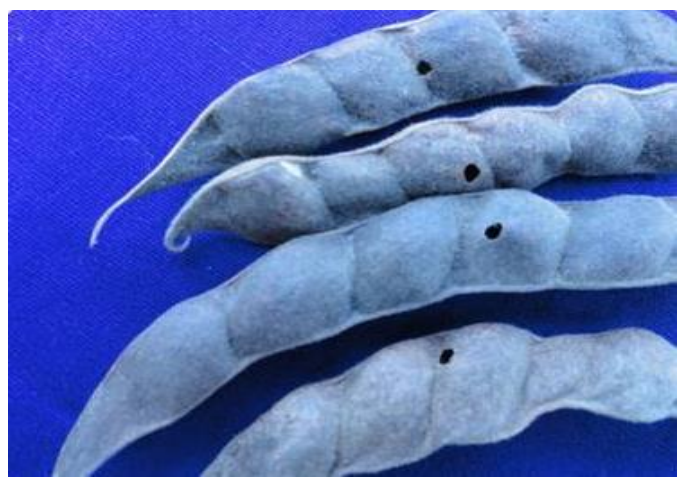

Callosobruchus spp.

Figure 1. Damage symptoms of pod borer complex in pigeonpea

\section{References}

Hillocks, R.J., Minja, E., Mwaga, A., Nahdy, M.S. and Subrahmanyam, P. (2000): Diseases and pests of pigeonpea in eastern Africa: a review. International Journal of Pest Management, 46: 7-18.

Panse, V. G. and Sukhatme, P.V. (1967): Statistical Methods for Agricultural Workers. ICAR, New Delhi, pp. 1-167.

Sunil, K., Singh, B. and Akhauri, R.K. (2004): Efficacy of some biorational insecticides on larval population of gram podborer on pigeonpea. Legume Research, 27: 62-65.

Kranthi, K.R., Jadhav, D.R., Kranthi, S., Wanjari, R.R., Ali, S.S., and Russel, D.A. (2002): Insecticide resistance in five major insect pests of cotton in India. Crop Protect. 21: 449-460.

Bhatnagar, V.S., Sithanantham, S., Pawar, C.S., Jadhav, D.S., Rao, V.K. and Reed, W. (1983): Conservation and augmentation of natural enemies with reference to IPM in chickpea and pigeonpea. In: Proceedings of the international workshop of integrated pest control in grain legumes, EMBRAPA Goiania, Brazil. 
Babu et al. 